\title{
Spacial and Temporal Variation of Degradation of Organic Matter by Benthic Macroinvertebrates
}

\author{
Ana Ribeiro $^{1,2}$, Natividade Vieira ${ }^{1,2}$ \\ ${ }^{1}$ Department of Biology, Faculty of Sciences, University of Porto, Porto, Portugal; ${ }^{2}$ CIMAR/CIIMAR-LA Interdisciplinary Centre of \\ Marine and Environmental Research, University of Porto, Porto, Portugal. \\ Email: ana_2_ribeiro@hotmail.com
}

Received July $17^{\text {th }}$, 2013; revised August $19^{\text {th }}$, 2013; accepted September $16^{\text {th }}, 2013$

Copyright (C 2013 Ana Ribeiro, Natividade Vieira. This is an open access article distributed under the Creative Commons Attribution License, which permits unrestricted use, distribution, and reproduction in any medium, provided the original work is properly cited.

\begin{abstract}
Leaf litter input from riparian landscapes has been identified as both a major energy flow to stream ecosystems and as a food source for stream macroinvertebrates. In this study the benthic macroinvertebrate community was used to evaluate the decomposition of organic matter in river systems. The aim of this work was to study the decomposition of organic matter using the benthic macroinvertebrate colonization. The research was developed over five months (January 2011 to May 2011) in four different sites, distributed along the River Ferreira terminal area, northern Portugal. A litter bag experiment was used to examine the role of macroinvertebrate communities in the processing of organic material on the river. Litter bags were placed in the water and collected every 7, 15, 30, 60, 90 and 120 days. In litter bags was observed a high abundance of Oligochaeta and Chironomidae, which are characterized by being detritivorous-herbivores and filtering collectors, respectively, indicating the benthic macroinvertebrate more involved on the decomposition of organic matter. These results contributed to increase current knowledge about benthic macroinvertebrate communities and may serve as incentive for future research works.
\end{abstract}

Keywords: Decomposition; Litter Bags; Macroinvertebrates; Organic matter

\section{Introduction}

The dynamics of organic matter is a process which is important for the functioning of aquatic ecosystems, because in addition to the recycling of nutrients, it contributes to the existence of organisms that feed on the same material. In this way, the organic matter in aquatic ecosystems has a fundamental role in many processes, focusing the decomposition [1].

In the biotic communities, benthic macroinvertebrates have a great importance in aquatic ecosystems, as they play an essential role in the process of organic matter decomposition, especially the allochthonous material [2], leaves from riparian trees. Leaves falling into the river systems may be transported over short distances, but usually are caught by structures, forming leaf litter beds [3]. The decomposition process involves various stages, beginning with the aging process of plant material, passing through various stages of death and gradually disintegration, until the release of several elements in different forms $[4,5]$.

The amount of leaf material has a great importance in the determination of abundance benthic macroinvertebrates [6], because it can operate as food substrate [7], and also function as a shelter against the current velocity and predators [8]. The decomposition of these wastes can cause changes in water quality, leading to anaerobic conditions and eutrophication.

In recent years several studies have investigated the decomposition of leaf litter in freshwater systems using leaves contained within litter bags $[9,10]$. Several studies suggest the use of litter bags in order to study the colonization of macroinvertebrates and how they participate in the degradation of organic matter [11,12]. The high abundance and diversity of macroinvertebrates that colonize the litter bags reinforce the importance of allochthonous plant material [13]. It is often assumed that leaves confined within litter bags will imitate natural leaf packs, and that the results of the decomposition and colonization investigations can be used to generalize about processes occurring naturally [12].

In this study, we used mixed litter bags, containing leaf material characterized at each sampling site and the 
main objective is to know which macroinvertebrates participate more in the process of decomposition of leaf material. Mixture of different leaf species were used to imitate natural accumulations in the stream and colonization was compared with that of naturally forming litter bags that were in the stream.

\section{Methods}

\subsection{Study Area}

This study was carried out on Ferreira River, situated to the North of Portugal and is in the Douro River basin. The first three sampling sites are located in the municipally of Gondomar and the last sampling sites are situated on the site of the natura 2000 in Valongo. In Figure $\mathbf{1}$ we can identify the four sampling sites that are part of this study.

\subsection{Communities of Benthic Macroinvertebrates}

This work was carried out an analysis of the plant species representative of each sampling site [14]. It was made a collection of leaf samples, present in the marginal vegetation of the river. The existing leaves on the trees in each sampling sites were collected even before abscission. The samples were placed in bags properly labeled with identification of each sampling site and were transported to the laboratory within a thermal box.

Plastic litter bags were built, with mesh of $10 \mathrm{~mm}$ [15] and with a size of $17 \mathrm{~cm} \times 25 \mathrm{~cm}$. These litter bags were then used to insert the leaf material which is characteristic of each sampling site, in order to be placed in the river, and then be colonized by macroinvertebrates.

In the laboratory the leaf material was identified and stored in a cool and dry place until further use. Immediately before the leaf material was used, it was properly cleaned and placed in an oven at $50^{\circ} \mathrm{C}$ for approximately 48 hours.
Within the litter bags were placed $4 \mathrm{~g}$ of leaf mixed species. After the leaf material is contained in litter bags, these were closed with string and then were wetted with pure water during transport to the river, to avoid the breakage or loss of the material contained in litter bags.

The litter bags were submerged at four different sites (1, 2, 3 and 4) 12 in each sampling site, and in each litter bag was tied a stone to remain submerged during the entire time of experience and also to avoid losses. The rope used was not bright colors to avoid acts of vandalism [17]. These were still imprisoned the margins with the same type of rope in order to identify the place for later removal.

The collection of litter bags was carried out between January and May (year of 2011), at the following sampling time: 7, 15, 30, 60, 90 and 120 days of exposure of litter bags in the water system. At each sampling site, litter bags were removed for later analysis of samples in the laboratory. At the time of collection of litter bags sometimes used the hand network to help its removal from the river. Each sample was placed into a plastic bag and transported to the laboratory in an icebox.

In the laboratory the leaf material contained in each litter bag was placed in a set of sieves with mesh of 500 and $100 \mu \mathrm{m}$ and was carefully washed, to remove sediment and other materials without relevance for the experience. Macroinvertebrates were separated, sorted and identified to the lowest taxonomic level as possible, according with Tachet et al. (2003) [17]. The leaf material was placed in an oven at $50^{\circ} \mathrm{C}$ for approximately $48 \mathrm{~h}$. Then this material was burned in a muffle at $550^{\circ} \mathrm{C}$ for approximately 5 hours, to know the content of organic matter lost during the exposure of litter bags on the river system. This value is obtained by the difference between the initial weight (before the incineration; in the oven) and the final weight (after incineration; in the muffle), according to Benfield (1996) [16].

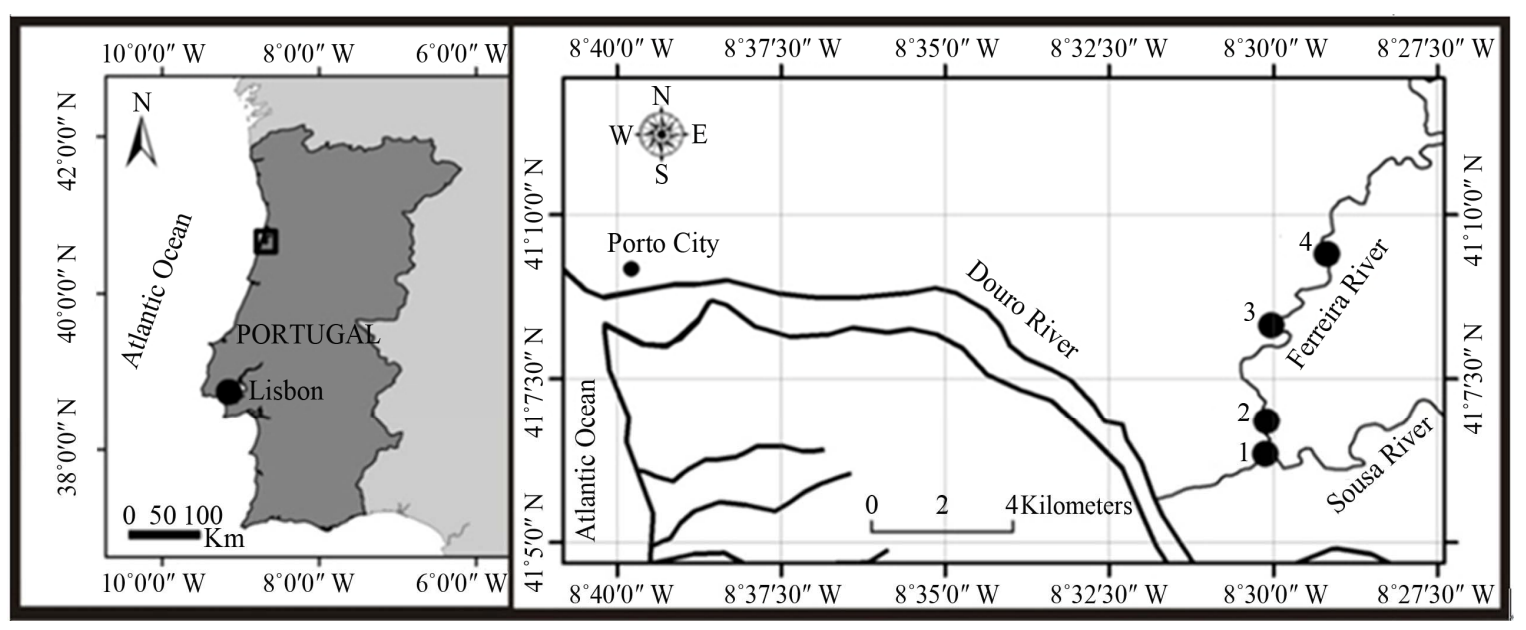

Figure 1. The study sites. 


\subsection{Data Analysis}

The results were analyzed using the Microsoft Office Excel 2010 and the program CAP 4 (Community analysis package 4; Company PISCES Conservation LDA).

In the statistical analysis it was used only one type of technique in accordance with the existing data and with the objectives that we wanted to achieve that was the Principal Component Analysis (PCA).

\section{Results}

\subsection{Benthic Macroinvertebrates Associated with the Decomposition of Organic Matter}

Through Figure 2, which represents the weight loss (g) of the plant material in litter bags we can verify that the highest weight loss occurs within the first 15 days of colonization of macroinvertebrates and consequent decomposition of leaf material. Other works demonstrated that leaf colonization by macroinvertebrates was highest in the early stages of decomposition [18]. These first 15 days of decomposition happens in winter (January) and according to the author Dobson (1991), the decomposition will be faster in winter, rain a lot during the month January on 2011. As expected, over time of collecting samples, the values for the leaf mass loss will decrease.

Twenty nine taxa were found during the five months of study. A total of 10,738 benthic macroinvertebrates were collected from litter bags.

Through the analysis of Figure 3 there was a high abundance of benthic macroinvertebrates inside litter bags at the end of 60 days for conditioning in stream, with the exception of site 1 , where it was not possible the collection of litter bag. But since there is a pattern of variation in total abundance of organisms, it is likely that there will be a high number of macroinvertebrates in site 1 , also at the end of 60 days of exposure of litter bags on the river. Site 4 has a high abundance of macroinvertebrates, with a total of 2696 organisms to colonize the leaf material contained inside the litter bag. There was a decrease in total abundance of organisms for 7 to 15 days of immersion. The day 15 until day 60, the total abundance of organisms will gradually increasing. The day 60 is one that has a higher total abundance of benthic macroinvertebrates inside litter bags, which highlights the site 4 . On the day 90 there was a decline in total abundance in relation to the day 60 , followed by a slight increase in the order of 120 days of immersion in the sites 3 and 4 only, since in sites 1 and 2 it was not possible for the collection of litter bags due to its disappearance in the course of water. But as has been said above, the abundance of organisms in sites 1 and 2 were increased slightly following the pattern of variation of the remaining sampling sites.

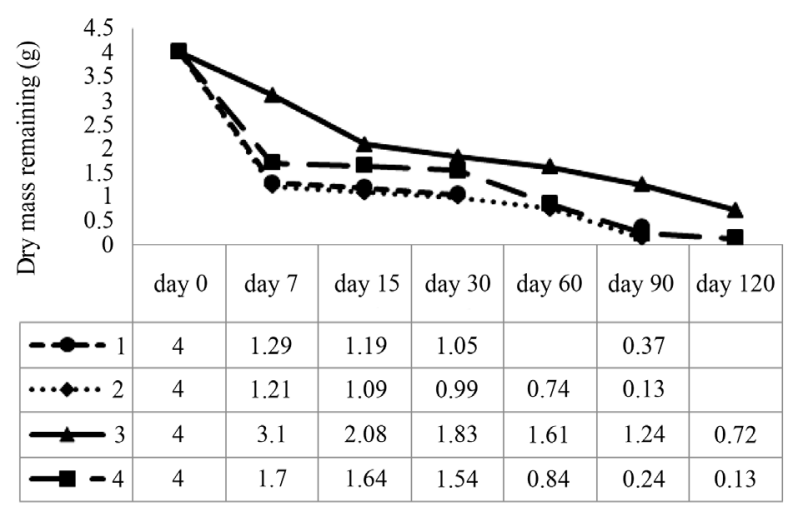

Figure 2. Weight loss (g) of the plant material contained in litter bags along the immersion time, for each sampling site.

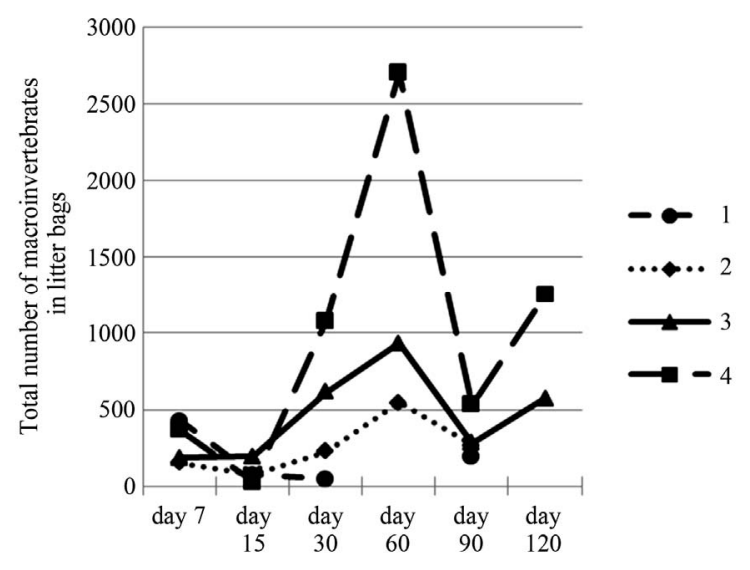

Figure 3. Total abundance of benthic macroinvertebrates in litter bags along the time of sampling.

About the taxonomic groups present in litter bags it has been found that the process of succession observed was initiated by the Oligochaeta and Diptera organisms.

Through the analyze of Figure 4 it has been found that at the end of 7 days of immersion, the sites 1,3 and 4 showed a high percentage of Oligochaeta (95\%, 95\% and $70 \%$ respectively) and a lower percentage of Diptera. In site 2 it was found the opposite of the remaining sampling sites (83\% of Diptera and only 16\% Oligochaeta). Of these, $83 \%$ belongs to the group Diptera, great part belongs to the family Chironomidae and according to several studies the Chironomidae are the first colonizers $[19,20]$ and are one of the taxonomic groups present in high numbers on the rivers [21]. On day 15 was visible a decrease of Diptera and an increase of Oligochaeta, in relation to the day 7 , in site 1 . At site 2, Diptera were the dominant group, while in site 3 , the Oligochaeta were the dominant group. In site 4, it did not found a marked predominance of taxonomic groups, we found Oligochaeta, Trichoptera, Gasteropoda and Odonata. Thus, the site 4 at the end of 15 days had a higher diversity of taxonomic groups. At the end of 30 days of immersion were ob- 


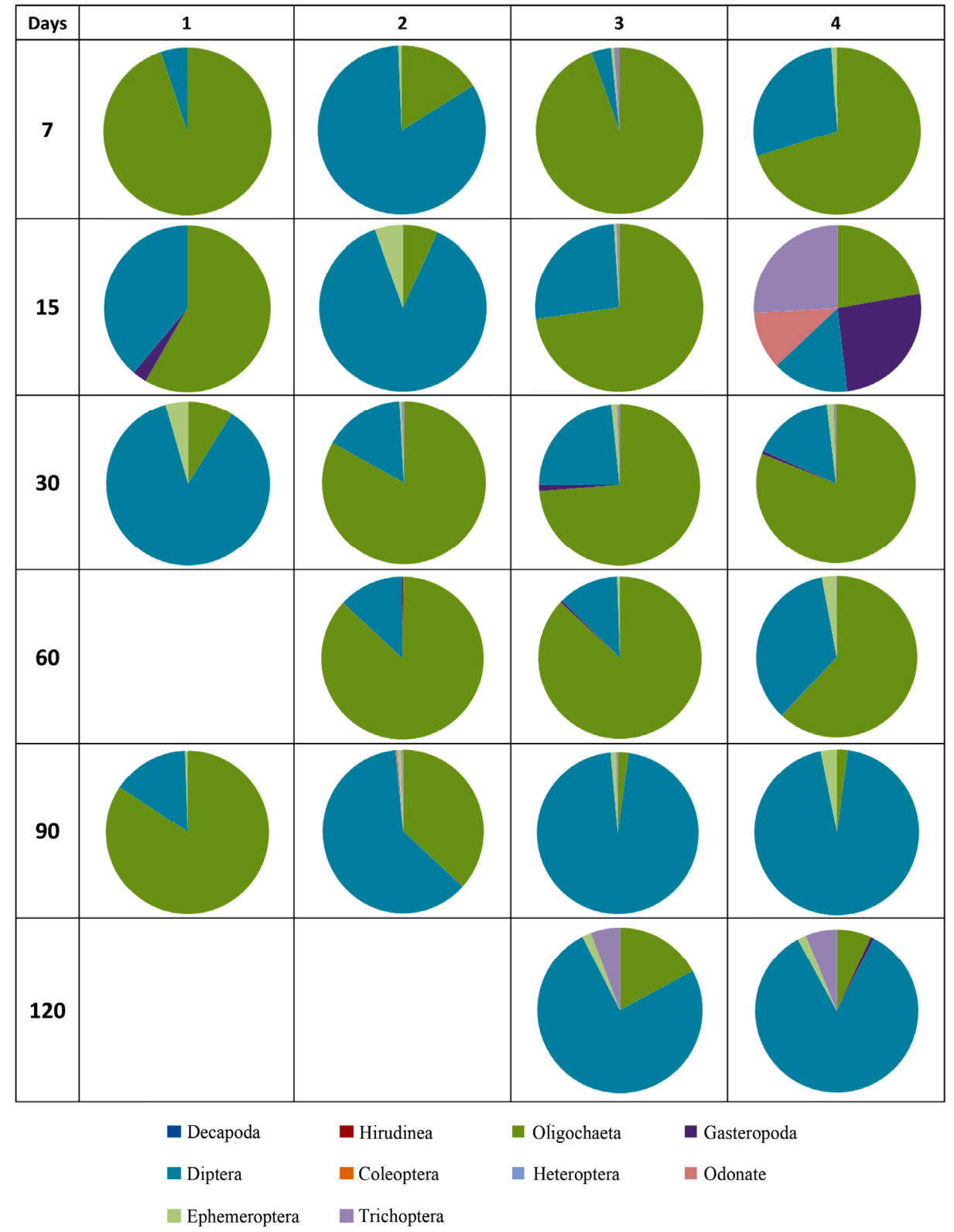

Figure 4. Taxonomic Groups of benthic macroinvertebrates present in litter bags, in four sampling sites $(1,2,3,4)$ along with 7, 15, 30, 60, 90 and 120 days of exposure of litter bags on the river.

served a dominance of Diptera in site 1 , while in the remaining sampling sites there was a predominance of Oligochaeta. It should be noted that in all sampling sites were present the taxonomic groups Oligochaeta, Diptera and Ephemeroptera. On day 60, in site 1, was not possible to have a collection of their litter bags. In sites 2, 3 and 4, the Oligochaeta organisms were dominant. For the day 90, site 1 has a higher percentage of Oligochaeta and the Diptera were dominant. For the day 120, at the sites 1 and 2, it was not possible to collect the litter bag due to acts of vandalism (the litter bags were polled out of water). In sites 3 and 4 we observed a predominance of Diptera, and low percentage the Oligochaeta, Trichoptera and Ephemeroptera organisms. The scarcicity of Odonata and Trichoptera organisms may indicate difficulty in enters the litter bags because the medium mesh size bags that were used in this study. The author Varga (2001) also found the same situation referred above.

\subsection{Functional Feeding Groups of Benthic Macroinvertebrate Communities in Litter Bags}

At site 1 were identified a total of 737 macroinvertebrates in the sampling of litter bags (Figure 5). There is a predominance of detritivorous herbivores (Oligochaeta) 

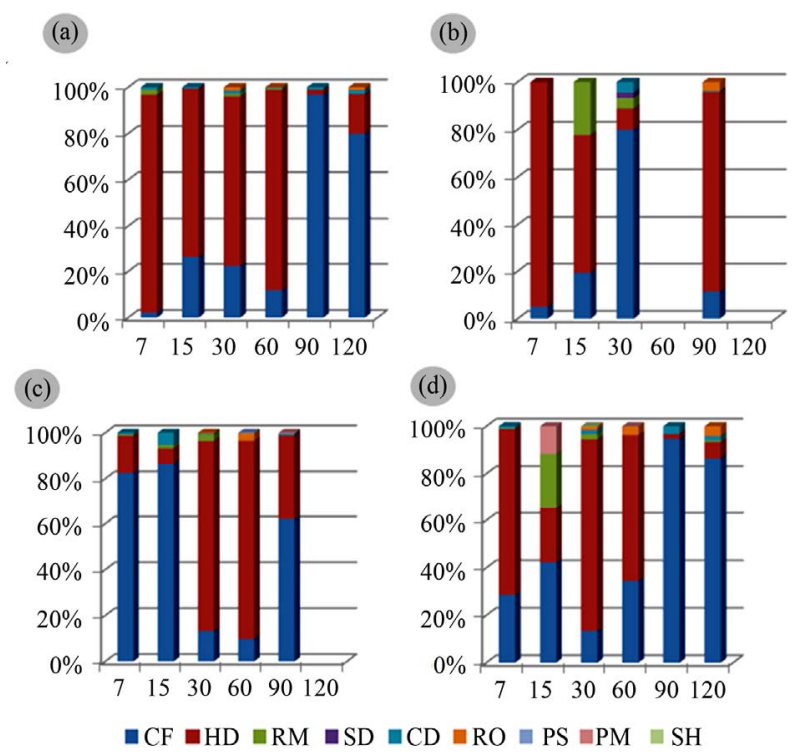

CF-Filtering Collectors; HD-Detritivorous Herbivores; RM-Mineral Scrapers; SD—Detritivorous Shredders; CD—Detritivorous Collectors; RO -Organic Scrapers; PS-Sucking Predators; PM-Mineral Predators; SH-Herbivorous Shredders.

Figure 5. Percentage Distribution of macroinvertebrates identified in four sampling sites $(1,2,3,4)$ at litter bags, over the 120 days of immersion.

(95\%) at the end of 7 days of immersion and the remaining $5 \%$ were filtering collectors (Diptera). At the end of 15 days of immersion, we observed the emergence of mineral scrapers (Gasteropoda) and continued to be present detritivorous herbivores and filtering collectors. On the day 30 appears detritivorous collectors (Ephemeroptera), detritivorous shredders (Diptera, family Tipulidae), mineral scrapers (Diptera, family Dixidae) and continued to persist the detritivorous herbivores, at a lower percentage, and filtering collectors occupying the highest percentage of organisms. At day 90, there was a quite similar situation in relation to the composition of the functional feeding groups for the day 7 , with the exception of the appearance of organic scrapers (Diptera, Chirinomidae, Caenidae) and detritivorous collectors (Diptera). During this period study, Oligochaeta was present in highest numbers.

At site 2 we can verify that on 7 and 15 days of exposure of litter bags in Ferreira River, the composition of the functional feeding groups was the same, and there is a predominance of filtering collectors, followed by a lower percentage of detritivorous herbivores, detritivorous collectors and mineral scrapers. At the end of 30 and 60 days after it has been found that the functional feeding groups were similar between the two sampling sites, there is a predominance of detritivorous herbivores, with the emergence of other functional feeding groups. The day 90 it was found that filtering collectors and they was the most abundant.
In site 3 we observed a high percentage of detritivorous herbivores (Oligochaeta) in the days 7, 15, 30 and 60 of immersion. There were a low percentage of collectors filterers in these days, there are also other functional feeding groups in low percentage. At the end of 90 days of immersion, $97 \%$ of macroinvertebrates were filtering collectors, $2 \%$ of detritivorous herbivores and only $1 \%$ of detritivorous collectors. The functional feeding group with higher percentage in 120 days was the filtering collectors (80\%), followed by the categories of detritivorous herbivores (17\%), detritivorous collectors (2\%) and only $1 \%$ of organic shredders. It seems that in site 3 there was a similar pattern in the composition of food categories at the end of 7, 15, 30 and 60 days of immersion, as well as the end of 90 and 120 days there is also a high physiologic similarity food.

Comparing Figure 5 on the site 4, with the site 3, there is a pattern of similarity in food categories, except for the day 15. On days 7, 30 and 60 there was also a predominance of detritivorous herbivores, while in the days 90 and 120 there was a higher dominance of filtering collectors. On day 15 it was verified the presence of two different taxonomic groups along the time, the predators (Gasteropoda) and mineral scrapers. In general, and taking into account the temporal variation, in site 4 it was found a balance between detritivorous herbivores and filtering collectors.

In this study, we identified the nine categories of feeding groups present in litter bags over the time of exposure in Ferreira River, being the filtering collectors present in higher numbers (5986 individuals) following the detritivorous herbivores, with 4346 organisms (Chironomidae and Oligochaeta). These results give us an indication of the organisms that more participated in the process of decomposition of leaf material in real time on the river.

\subsection{Statistical Analysis on the Communities of Benthic Macroinvertebrates in Litter Bags}

The Principal Components Analysis (PCA) is a method of ordering that transforms the original variables correlated among themselves, in new variables not correlated [22].

The analysis of Figure 6 highlights the existence of the gradients (spatial and temporal) in respect of the distribution of the samples, which translates into a higher variety of functional feeding groups amount sites 3 and 4 (upstream) in relation to downstream (sites 1 and 2). The number of macroinvertebrate taxonomic groups through the time of exposure also decreases further downstream.

\section{Discussion}

The biggest weight loss observed in the first fifteen days 


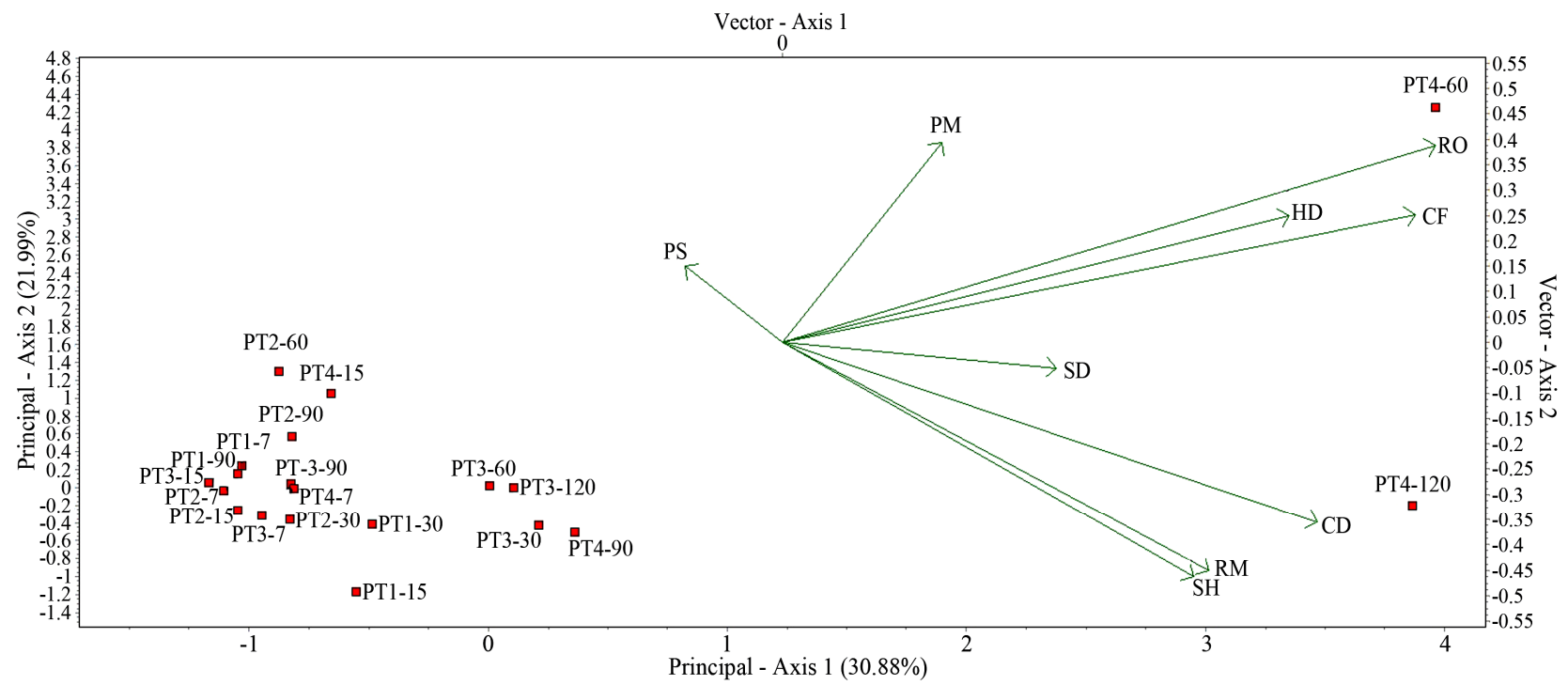

Figure 6. Ordination of the different functional groups food in different litter bags over 120 days of exposure in the aquatic environment in four sampling sites.

of colonization is related in part to the leaching of soluble organic compounds in water [23]. According to the study developed by Matos et al. (2007), in the course of time, the rate of weight loss is reduced due to the process of decomposition of organic compounds more resistant and stable that constitutes the leaf (lignin and cellulose). These first 15 days of decomposition occurred in month of January and according to the author Dobson (1991), the decomposition will be faster in winter, where there is the highest flow and the currents are stronger. Other studies have reported that the reduction of the rate of flow is increasing the capacity of retention, contributing to the colonization by detritivorous that accelerate the process of decomposition [24]. It is also known that the increase in temperature can induce an increase in the decomposition rate [25-27]. Decomposition depends not only on the quantity of organisms, but their functional feeding groups, once the leaf material will be consumed in accordance with the food preferences of the existing communities in each sampling site. A higher current speed contributes to a greater oxygenation within the litter bags, which is essential for the proper functioning of the community decomposition of leaf material [28]. Thus, the increase of this factor may contribute to the faster decomposition of leaf material [29]. The decomposition rate can be used as indicators of the functional state of the river, since associating the macroinvertebrates decomposition. This idea was proposed by Gessner \& Chauvet (2002) [30]. They can be various causes or factors responsible for different answers on the loss of leaf mass over time in different sampling sites and the results can be masked by possible problems, related to the technique, the use of the material pre-treaty and the containment of waste in leaf litter bags [9]. According to the authors Boulton and Boon (1991)
[31], the use of litter bags was criticized due to the fact that reduce water exchanges and abrasion.

The decrease in total abundance of organisms from 7 to 15 days of immersion may be probably explained due to rainfall, increasing the speed of flow and consequent washing of invertebrates, considerably reducing their number, according Thomazi et al. (2008). Environmental factors contributed to the fluctuations in richness of groups and in density of benthic macroinvertebrates [32]. The day 60 is one that has a higher total abundance of benthic macroinvertebrates inside litter bags, which highlights the site 4 . This fact can be explained possibly due to the consequent increase of the vegetation in this sampling site, improving the presence of a high number of organisms. Many invertebrates using the leaf material contained in litter bags as a food resource [33] and it is known that their abundance depending on climate and other factors, such as substrate texture, biotic and physical-chemical parameters [34].

As regards the taxonomic groups present in litter bags it has been found that the succession process was initiated by Oligochaeta and Diptera. The Oligochaeta has high variety of food items and when there were leaf accumulations into the aquatic system, there is a higher surface area, promoting the development of microorganisms and consequent abundance [35]. Chironomidae larvae are known to eat a variety of food types, such as for example, algae, detritus, macrophytes and invertebrates $[36,37]$. It is also known that the fine particulate organic matter (FPOM) that is retained within the litter bags can be used by the Chironomidae for construction of tubes that function as shelters, which may explain their high abundance in litter bags [38].

In this study, we used mixed litter bags [39] suggested 
that these differ in the decomposition rate in relation to litter bags of unique species, but still found that there is a similarity in colonization patterns of macroinvertebrates. However, Cortes et al. (1997) [40] concluded that, in streams, the food availability is high and there is no particular reason for the macroinvertebrates aggregate in litter bags.

The colonization makes it possible to get to know the macroinvertebrates presents in the river system, but also enables the analysis of the changes that occur in the composition of the community over time [41,42]. As we observed, litter bags were rapidly colonized by macroinvertebrates, this event is also found by Hieber \& Gessner (2002). At site 1 we observe a dominance of detritivorous herbivores and according to the study of Carvalho \& Uieda (2004) the Oligochaeta are excellent initials colonizers, hence the high percentage was observed at the end of 7 days. Thus, it has been found that the detritivorous herbivores and filtering collectors remained during all the days of colonization, the Oligochaeta (detritivorous herbivores) are the most abundant. It can be seen that, in site 3 there was a similar pattern in the composition of food categories at the end of 7, 15, 30 and 60 days of immersion, as well in the days 90 and 120 there is also a great physiologic similarity food. In site 4 it was found a balance between detritivorous herbivores and filtering collectors.

These results give us an indication of the organisms that more participated in the process of decomposition, which is Oligochaeta and Chironomidae (Diptera). However, if the study is prolonged in time and if the sampling effort was greater, possibly the results would be more conclusive.

\section{REFERENCES}

[1] J. C. R. Azevedo, A. Mizukawa, M. C. Teixeira and T. A. Pagioro, "Contribuição da Decomposição de Macrófitas Aquáticas (Eichhornia azurea) na Matéria Orgânica Dissolvida” Oecologia Brasiliensis, Vol. 12, No. 1, 2008, pp. 42-56.

[2] R. L. Vannote, G. W. Minshall, K. W. Cummins, J. R. Sedell and C. E. Cushing, "The River Continuum Concept," Canadian Journal of Fisheries and Aquatic Sciences, Vol. 37, No. 1, 1980, pp. 130-137. http://dx.doi.org/10.1139/f80-017

[3] E. A. Flory and A. M. Milner, "Influence of Riparian Vegetation on Invertebrate Assemblages in a Recent Formed Stream in Glacier Bay National Park, Alaska," Journal of the North American Benthological Society, Vol. 18, No. 2, 1999, pp. 261-273.

http://dx.doi.org/10.2307/1468464

[4] B. Gopal and V. Masing, "Wetlands and Shallow Continental Water Bodies. Netherlands,” In: D. C. Patten, Ed., Biology and Ecology, Vol. 1, SPC Academic Publishing, 1990, pp. 91-239.
[5] J. G. Kim and E. Rejmánková, "Decomposition of Macrophytes and Dynamics of Enzyme Activities in Subalpine Marshes in Lake Tahoe Basin, USA,” Plant and Soil, Vol. 266, No. 1-2, 2004, pp. 303-313.

http://dx.doi.org/10.1007/s11104-005-1360-2

[6] W. E. Barber and N. R. Kevern, "Ecological Factors Influencing Macroinvertebrate Standing Crop Distribution," Hydrobiologia, Vol. 43, No. 1-2, 1973, pp. 53-73. http://dx.doi.org/10.1007/BF00014257

[7] J. S. Richardson, "Food, Microhabitat, or Both? Macroinvertebrate Use Leaf Accumulations in a Montane Stream," Freshwater Biology, Vol. 27, No. 2, 1992, pp. 169-176. http://dx.doi.org/10.1111/j.1365-2427.1992.tb00531.x

[8] H. J. Egglishaw, "The Distributional Relationship between the Bottom Fauna and Plant Detritus in Streams,” Journal of Animal Ecology, Vol. 33, No. 3, 1964, pp. 463-476. http://dx.doi.org/10.2307/2566

[9] F. Barlocher, "Pitfalls of Tradicional Techniques When Studying Decomposition of Vascular Plant Remains in Aquatic Habitats,” Limnética, Vol. 13, No. 2, 1997, pp. 111.

[10] J. R. Webster and J. B. Waide, "Effects of the Forest Clearcutting on Leaf Breakdown in a Southern Appalachian Stream,” Freshwater Biology, Vol. 12, No. 4, 1982, pp. 331-344. http://dx.doi.org/10.1111/j.1365-2427.1982.tb00627.x

[11] T. B. Matos, E. Bernini and C. E. Rezende, "Decomposição de Folhas de Avicennia Germinans, Rhizophora Mangle e Laguncularia Racemosa do Manguezal do Estuário do rio Paraíba do Sul, Estado do Rio de Janeiro," 2007.

[12] M. Dobson, “An Assessment of Mesh Bags and Plastic Leaf Traps as Tool for Study Macroinvertebrates. Assemblage in Natural Leaf Packs,” Hydrobiologia, Vol. 222, No. 1, 1991, pp. 19-28. http://dx.doi.org/10.1007/BF00017496

[13] E. Carvalho, "Dinâmica do Aporte de Material Alóctone e de Seu Processamento por Invertebrados Bentônicos em um Riacho Tropical,” Instituto de Biociências, Botucatu, São Paulo, 2008.

[14] INAG, “Manual de Avaliação Biológica da Qualidade da água em Sistemas Fluviais Segundo a Directiva Quadro da Água: Protocolo de Amostragem e Análise Para Macrófitos," Lisboa. Ministério do Ambiente, do Ordenamento do Território e do Desenvolvimento Regional, Instituto da Água, 2008.

[15] R. A. Stockley, G. S. Oxford and R. F. G. Ormond, "Do Invertebrate Matter? Detrital Processing in the River Swale-Ouse,” The Science of the Total Environment, Vol. 210-211, 1998, pp. 427-435. http://dx.doi.org/10.1016/S0048-9697(98)00029-1

[16] E. F. Benfield, "Leaf Breakdown in Stream Ecosystems. Methods in Stream Ecology,” Chapter 27, 1996.

[17] H. Tachet, P. Richoux, M. Bournard and P. Ussegliopolatera, "Invertébrés d'eau douce-Systematique, Biologie, Écologie,” 2003.

[18] H. Walpola, M. Leichtfried, M. Amarasinghe and L. Fureder, "Leaf Litter Decomposition of Three Riparian Tree Species and Associated Macroinvertebrates of Eswathu Oya, a Low Order Tropical Stream in Sri Lanka," 
International Review of Hydrobiology, Vol. 96, No. 1, 2011, pp. 90-104.

http://dx.doi.org/10.1002/iroh.201011248

[19] I. Varga, "Macroinvertebrates in Reed Litter," International Review of Hydrobiology, Vol. 86, No. 4-5, 2001, pp. 573-583.

http://dx.doi.org/10.1002/1522-2632(200107)86:4/5<573: :AID-IROH573>3.3.CO;2-0

[20] R. D. Thomazi, W. P. Kiifer, P. D. Ferreira and F. S. Sá, “A Sucessão Ecológica Sazonal de Macroinvertebrados Bentónicos em Diferentes Tipos de Atratores Artificiais no rio Bubu, Cariacica, ES,” 2008.

[21] E. I. Meyer and R. Poepperl, “Assessing Food-Web Structure, Matter Fluxes, and System Attributes of a Cen- tral European Mountain Stream by Performing Mass- Balanced Network Analyses," Canadian Journal of Fisheries and Aquatic Sciences, Vol. 61, No. 9, 2004, pp. 15651581. http://dx.doi.org/10.1139/f04-104

[22] X. Bry, “Analyses Factorielles Simples,” 1995.

[23] F. M. M. Chale, "Degradation of Mangrove Leaf Litter under Aerobic Conditions,” Hydrobiologia, Vol. 257, No. 3, 1993, pp. 177-183. http://dx.doi.org/10.1007/BF00765010

[24] P. L. Thompson and F. Barlocher, "Effect of pH on Leaf Breakdown in Streams and in the Laboratory," Journal of the North American Benthological Society, Vol. 8, No. 3, 1989, pp. 203-210. http://dx.doi.org/10.2307/1467323

[25] J. H. Braatne, P. Sullivan and E. Chamberlain, "Leaf Decomposition and Stream Macroinvertebrate Colonization of Japanese Knotweed, an Invasive Plant Species,” International Review of Hydrobiology, Vol. 92, No. 6, 2007, pp. 656-665. http://dx.doi.org/10.1002/iroh.200611009

[26] R. M. Cortes, M. A. S. Graça, J. N. Vingada and S. Varandas de Oliveira, "Stream Typology and Dynamics of Leaf Processing,” Annis. Limn., Vol. 31, No. 2, 1995, pp. 119-131. http://dx.doi.org/10.1051/limn/1995008

[27] R. C. Petersen and K. W. Cummins, "Leaf Process in a Woodland Stream,” Freshwater Biology, Vol. 4, No. 4, 1974, pp. 343-368. http://dx.doi.org/10.1111/j.1365-2427.1974.tb00103.x

[28] A. M. M. Mesquita, "Decomposição da Folhada de Eucalyptus Globules em Sistemas Lóticos: Papel dos Macroinvertebrados e dos Fungos Aquáticos,” 2003.

[29] M. Abelho, "Effects of Leaf Litter Species on Macroinvertebrate Colonization during Decomposition in a Portuguese Stream,” International Review of Hydrobiology, Vol. 93, No. 3, 2008, pp. 358-371. http://dx.doi.org/10.1002/iroh.200711019

[30] M. O. Gessner and E. Chauvet, "A Case for Using Litter Breakdown to Assess Functional Stream Integrity," Ecological Applications, Vol. 12, No. 2, 2002, pp. 498-510. http://dx.doi.org/10.1890/1051-0761(2002)012[0498:AC FULB]2.0.CO;2

[31] J. Boulton and P. I. Boon, “A Review of Methodology Used to Measure Leaf Litter Decomposition in Lotic En- vironments: Time to Turn over an Old Leaf?” Australian Journal of Marine and Freshwater Research, Vol. 42, No. 1, 1991, pp. 41-43. http://dx.doi.org/10.1071/MF9910001

[32] F. J. P. Abílio, A. A. F. Essner, R. L. Leite and T. L. M. Riffo, "Gastrópodes Outros Invertebrados do Sedimento e Associados à Macrófitas Eichhornia Crassipes de um Açude Hipertrófico o Semi-Árido Paraibano,” Revista de Biologia Ciências a Terra, Vol. 2, No. 1, 2006, pp. 165178.

[33] M. A. S. Graça and C. Canhoto, "Leaf Litter Processing in Low Order Streams,” Limnetica, Vol. 25, No. 1-2, 2006, pp. 1-10.

[34] S. Fenoglio, P. Agosta, T. Bo and M. Cucco, "Field Experiments on Colonization and Movements of Stream Invertebrates in an Apennine River (Visone, NW Italy)," Hydrobiologia, Vol. 474, No. 1, 2002, pp. 125-130. http://dx.doi.org/10.1023/A:1016525315671

[35] E. Chauvet, N. Giani and M. O. Gessner, "Breakdown and Invertebrate Colonization of Leaf Litter in Two Contrasting Streams: Significance of Oligochaetes in a Large River," Canadian Journal of Fisheries and Aquatic Sciences, Vol. 50, No. 3, 1993, pp. 488-495.

http://dx.doi.org/10.1139/f93-057

[36] M. Callisto, J. R. Gonçalves and M. A. S. Graça, "Leaf Litter as a Possible Food Source for Chironomids (Diptera) in Brazilian and Portuguese Headwater Streams," Revista Brasileira de Zoologia, Vol. 24, No. 2, 2007, pp. 442-448. http://dx.doi.org/10.1590/S0101-81752007000200023

[37] R. L. Motta and V. S. Uieda, "Diet and Trophic Groups of an Aquatic Insecto Community in a Tropical Stream," Brazilian Journal of Biology, Vol. 64, No. 4, 2004, pp. 110. http://dx.doi.org/10.1590/S1519-69842004000500010

[38] O. Dangles, F. Guerold and P. Usseglio-Polatera, "Role of Transported Particulate Organic Matter in the Macroinvertebrate Colonization of Litter Bags in Streams," Freshwater Biology, Vol. 46, No. 5, 2001, pp. 575-586. http://dx.doi.org/10.1046/j.1365-2427.2001.00693.x

[39] M. Abelho, "Leaf-Litter Mixtures Affect Breakdown and Macroinvertebrate Colonization Rates in a Stream Ecosystem," International Review of Hydrobiology, Vol. 94, No. 4, 2009, pp. 436-451.

[40] R. M. V. Cortes, M. Abelho and S. B. Rebelo, "The Macroinvertebrate Colonization of Leaf Bags: Is There a Pattern?” Limnetica, Vol. 13, No. 2, 1997, pp. 71-75.

[41] E. M. Carvalho and V. S. Uieda, "Colonização por Macroinvertebrados Bentónicos em Substrato Artificial e Natural em um Riacho da Serra de Itatinga, São Paulo, Brasil,” Revista Brasileira de Zoologia, Vol. 21, No. 2, 2004, pp. 287-293.

[42] R. N. Guereschi, "Macroinvertebrados Bentónicos em Córregos da Estação Ecológica de Jataí, Luiz Antônio, SP,” Universidade Federal de São Carlos, Tese de doutorado, 2004. 